MaPan : Jurnal Matematika dan Pembelajaran

p-ISSN: 2354-6883 ; e-ISSN: 2581-172X

Volume 6, No 1, June 2018 (20-30)

DOI: https://doi.org/10.24252/mapan.2018v6n1a3

\title{
PENGEMBANGAN BAHAN AJAR MATEMATIKA SMP BERWAWASAN NASIONALISME DAN KEMANDIRIAN
}

\author{
Salafudin'), Santika Lya Diah Pramesti2), Juwita Rini ${ }^{3)}$ \\ 1,2,3IAIN Pekalongan \\ 1,2,3Jl. Kusuma Bangsa No. 9 Kota Pekalongan \\ Email: nidusalaf@gmail.com ${ }^{1}$, santikalyadiah@gmail.com ${ }^{2}$, \\ juwita_rini91@yahoo.com ${ }^{3}$ )
}

Submitted: 19-02-2018, Revised: 03-05-2018, Accepted: 03-05-2018

\begin{abstract}
Abstrak:
Penelitian ini merupakan penelitian pengembangan bahan ajar matematika pokok bahasan geometri SMP dengan wawasan pendidikan karakter nasionalisme dan kemandirian. Penelitian ini bertujuan untuk mengetahui karakteristik bahan ajar matematika dengan wawasan nasionalisme dan kemandirian serta menghasilkan bahan ajar matematika dengan wawasan nasionalisme dan kemandirian yang praktis dan efektif dalam pembelajaran matematika. Metode penelitian menggunakan metode pengembangan Thiagarajan. Hasil penelitian menunjukkan bahwa bahan ajar matematika dengan wawasan nasionalisme dan kemandirian yang telah dikembangkan, yaitu valid, praktis, efektif. Kemampuan matematika siswa meningkat dan terjadi peningkatan karakter nasionalisme dan kemandirian pada siswa.
\end{abstract}

Kata Kunci: Bahan Ajar, Matematika, Geometri, Karakter Nasionalisme, Karakter Kemandirian

\section{DEVELOPING MATHEMATICS TEACHING MATERIAL THAT INCLUDES NATIONALISM AND SELF-RELIANCE FOR JUNIOR HIGH SCHOOL}

\begin{abstract}
:
This is a research on developing mathematics teaching material, on geometry, that includes teaching nationalism and self-reliance insight for junior high school level. This research aims to know the characteristics of mathematical teaching materials that includes nationalism and self-seliance insight, produce practical mathematics materials that includes nationalism and self-reliance insight to be implemented effectively in teaching mathematic. This research applied Thiagarajan method. The study results showed that the learning tools developed were valid, practice, and effective. Based on the improvement on students' mathematical competencies and students' nationalism and self-reliance insight.
\end{abstract}

Keywords: Teaching Material, Mathematics, Geometry, Character Nationalism, Character Self-Reliance 
How to Cite: Salafudin, Pramesti, L.D. \& Rini, J. (2018). Pengembangan Bahan Ajar Matematika SMP Berwawasan Nasionalisme dan Kemandirian. MaPan : Jurnal Matematika dan Pembelajaran, 6 (1), 20-30.

$\mathrm{P}$ endidikan pada hakikatnya adalah usaha sadar untuk mengembangkan kepribadian dan kemampuan di dalam dan di luar sekolah yang berlangsung seumur hidup. Usaha itu dilakukan untuk membentuk warga negara yang bertanggungjawab atas terselenggaranya masyarakat Indonesia yang adil dan makmur, baik spiritual maupun material. Ini berarti bahwa pendidikan tidak hanya menjadi proses transfer ilmu pengetahuan dari guru pada anak didik, tetapi juga diharapkan mampu menjadi sarana proses internalisasi nilai dan pembentukan karakter, antara lain jiwa nasioanalisme dan kemandirian.

Pembentukan kepribadian dalam kehidupan bermasyarakat sejalan dengan fungsi dari pendidikan nasional di Indonesia. Akan tetapi, pada kenyataannya sekarang ini banyak ditemukan penyimpangan-penyimpangan moral yang terjadi di kalangan anak-anak sekolah seperti, tawuran antar sekolah, seks bebas, narkoba dan sebagainya (Mantiri, 2014). Menurut (Mu'in, 2011) beberapa masalah yang dihadapi bangsa ini antara lain: dominasi budaya membodohi akibat tayangan yang tidak mendidik dalam tayangan media, adanya korupsi yang meluas dan masih menggerogoti bangsa dan kerusakan lingkungan alam akibat ulah manusia. Hal tersebut menunjukkan betapa rendahnya rasa cinta tanah air yang dimiliki bangsa Indonesia. Berdasarkan hal tersebut, dirasakan sangat perlu diterapkannya pendidikan karakter dalam setiap aspek bidang ilmu, termasuk matematika.

Matematika sebagai bagian dari kurikulum pendidikan menjadi salah satu sarana bagi pencapaian tujuan pendidikan. Matematika merupakan pengetahuan dasar yang diperlukan oleh peserta didik. Nilai penting matematika bukan hanya dalam konteks pencapaian tujuan pendidikan dalam aspek kognitif berupa penguasaan matematika melainkan juga dalam aspek afektif berupa adanya perubahan sikap dan tingkat laku anak didik yang mencakup di dalamnya sikap kemandirian dan juga kecintaan terhadap negara dan bangsa (Jujun, 2001). Matematika dalam tradisi ilmiah seringkali dikaitkan dengan pendidikan karakter. Hal ini dikarenakan dalam mengajarkan matematika akan menanamkan rasa cinta di hati anak-anak akan kebenaran, benci pengkhianatan dan kepalsuan serta memunculkan sikap kemandirian (Mulyadi, 2011). Dengan demikian, pembelajaran matematika 
diharapkan mengantarkan siswa pada keberhasilan belajar matematika yang diwujudkan dalam bentuk prestasi akademik, juga adanya pembentukan karakter mandiri, tekun, jujur, cinta dan setia termasuk cinta dan setia kepada negara dan bangsa. Dengan kata lain, melalui pembelajaran matematika dapat ditanamkan nilai-nilai nasionalisme dan kemandirian pada anak.

Harapan tersebut di atas tidak sepenuhnya bisa terwujud dalam praktek di lapangan. Ada kecenderungan motivasi mempelajari matematika semata hanya untuk kepentingan pragmatis dan pengembangan keilmuan semata. Pembentukan karakter melalui pembelajaran matematika belum banyak terlihat, hal ini disebabkan paradigma integrasi keilmuan belum banyak menjadi pilihan. Seolah-olah tidak ada kaitan antara konsep keilmuan tertentu dengan pembentukan karakter, yang sejatinya dimunculkan dalam setiap disiplin ilmu (Muhibuddin, 2014). Keadaan demikian diperparah dengan minimnya muatan karakter, khususnya karakter nasionalisme dan kemandirian dalam bahan ajar yang digunakan dalam proses pembelajaran matematika.

Prastowo (2013) menyatakan bahwa dalam realita pendidikan terlihat banyak pendidik yang masih menggunakan bahan ajar yang siap pakai, instan, serta tanpa merencanakan, menyiapkan, dan menyusunnya sendiri. Kemungkinan resikonya adalah bahan ajar yang dipakai tidak kontekstual dan kurang mengintegrasikan nilai-nilai karakter. Hal ini sejalan dengan pendapat (Malik, 2005), bahwa tidak adanya pembentukan karakter dalam proses pembelajaran matematika diduga akibat dari beberapa faktor seperti: buku teks atau buku pelajaran (bahan ajar) yang digunakan kurang mengarah pada integrasi keilmuan antara matematika dengan agama dan budaya yang berkembang; penerapan strategi belajar-mengajar yang belum maksimal dan belum relevan dengan tuntutan kurikulum karena keterbatasan kemampuan pendidik; dan lingkungan belajar (hidden curricullum) belum kondusif bagi berlangsungnya suatu proses pembelajaran.

Salah satu usaha yang dapat dilakukan adalah dengan jalan memperbaiki faktor-faktor yang memungkinkan mempengaruhi hasil belajar siswa, antara lain faktor yang bersumber dari: guru, siswa, kurikulum, kualitas proses pembelajaran, fasilitas belajar, lingkungan belajar, dukungan biaya penyelenggaraan pendidikan, serta buku ajar. Dari sekian banyak faktor tersebut, faktor buku ajar dianggap cukup dominan dalam mempengaruhi pembentukan karakter. Buku ajar, termasuk buku ajar matematika harus diarahkan untuk memberdayakan semua potensi peserta didik memiliki kompetensi yang diharapkan termasuk pembentukan karakter nasionalisme dan kemandirian. 
Dewasa ini, banyak ditemukan penelitian tentang pengembangan bahan ajar yang berorientasi pada pengintegrasian nilai karakter. Diantaranya yaitu penelitian Usmaedi (2017), Nur (2017), Musfiqi dan Jailani (2014) yang menghasilkan bahan ajar matematika SMP Kelas VII yang valid, praktif, dan efektif untuk meningkatkan karakter dan HOTS (Higher Order Thinking Skills). Penelitian berikutnya yakni (Yunus dan Suyitno, 2013) yang menghasilkan bahan ajar matematika bermuatan pendidikan karakter religi, ingin tahu, mandiri, kritis logis, jujur, kerja keras, dan percaya diri pada materi bangun ruang sisi datar dengan pendekatan konstruktivisme yang praktis dan efektif.

Dari uraian tersebut, pendidikan termasuk di dalamnya pengajaran matematika, tidak hanya ingin mengantarkan peserta didik pada keberhasilan akademik, akan tetapi pendidikan juga diarahkan pada peningkatan nasionalisme siswa dan membentuk pribadi mandiri. Pengembangan bahan ajar matematika berwawasan nasionalisme dan kemandirian diduga merupakan suatu solusi bagi tercapainya harapan tersebut. Melalui penelitian pengembangan yang dilakukan secara kolaborasi antara guru dan peneliti ini dikembangkan bahan ajar matematika yang didesain untuk meningkatkan hasil belajar dan sikap nasionalisme dan kemandirian siswa.

Adapun tujuan penelitian ini untuk mengetahui karakteristik bahan ajar matematika dengan wawasan nasionalisme dan kemandirian serta menghasilkan bahan ajar matematika dengan wawasan nasionalisme dan kemandirian yang praktis dan efektif dalam pembelajaran matematika

\section{METODE PENELITIAN}

Pendekatan dalam penelitian ini adalah penelitian pengembangan, lebih khususnya penelitian ini merupakan penelitian pengembangan perangkat pembelajaran 4-D Thiagarajan. Desain penelitian yang digunakan adalah desain penelitian pengembangan perangkat pembelajaran dari (Thiagarajan, 1974) yang dimodifikasi. Desain pengembangan hasil modifikasi ini terdiri dari 3 tahap yaitu: Pendefinisian (Define), 2) Perancangan (Design), dan 3) Pengembangan (Develop) yang dapat digambarkan seperti tampak pada Gambar 1.

Desain penelitian uji coba bahan ajar matematika berwawasan nasionalisme dan kemandirian (MBNK) adalah true-experimental design dengan pre-test post-test control group design. Teknik pengumpulan data yang digunakan dalam penelitian ini adalah uji ahli, studi dokumentasi, observasi kelas, pengisian angket, wawancara, dan tes hasil belajar (pre-test dan post-test) dengan menggunakan bahan ajar MBNK. Instrumen angket digunakan untuk validasi ahli. Uji validasi ahli ini digunakan untuk memperoleh bahan ajar 
matematika bewawasan nasionalisme dan kemandirian yang valid berdasarkan pendapat pakar. Observasi kelas digunakan untuk mengumpulkan data mengenai aktivitas siswa selama kegiatan pembelajaran yang menggunakan bahan ajar MBNK. Observasi dilakukan oleh guru matematika dan teman sejawat berdasarkan format observasi yang telah disediakan oleh peneliti, sedangkan pengisian angket dilakukan oleh siswa untuk memperoleh data respon siswa dan guru terhadap penggunaan bahan ajar MBNK. Di samping itu, dilakukan juga wawancara terhadap guru untuk memperoleh data respon siswa dan guru terhadap penggunaan bahan ajar MBNK yang dikembangkan. Terakhir, soal-soal tes digunakan untuk memperoleh data tentang efek potensial (potential effect) bahan ajar MBNK terhadap hasil belajar siswa.

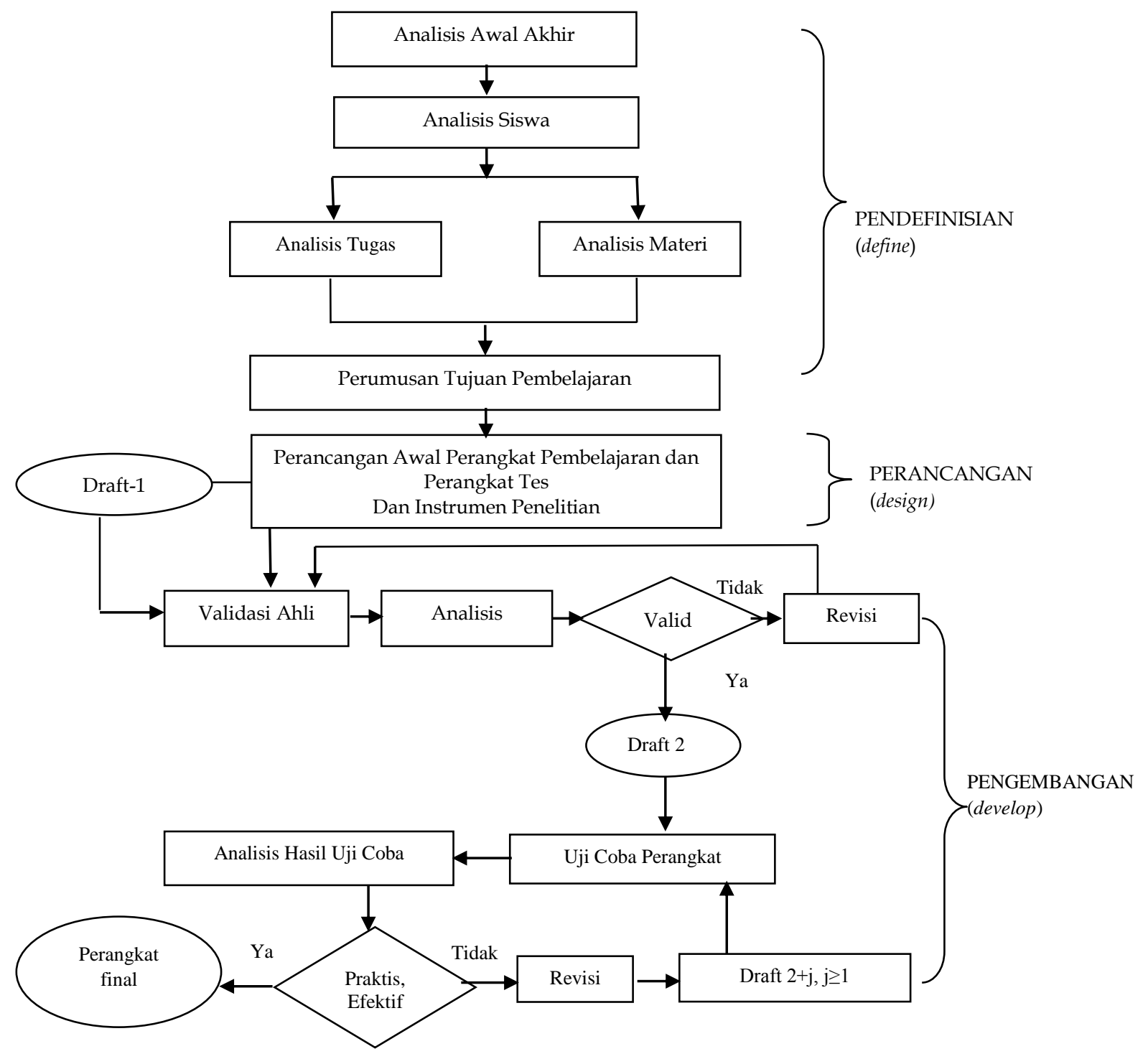

Gambar 1. Pengembangan Perangkat Model 3-D 
Sumber data dalam penelitian ini adalah siswa dari $3 \mathrm{SMP} / \mathrm{MTs}$ di wilayah Karesidenan Pekalongan, yaitu dari SMPIT Assalam Kota Pekalongan (Kelas Eksperimen A), SMP Negeri I Wiradesa Kabupaten Pekalongan (Kelas Eksperimen B) dan MTs N Tegal (Kelas Eksperimen C).

Penilaian bahan ajar (MBNK) berdasarkan dengan rubrik dari masingmasing indikator yang telah dibuat oleh peneliti. Data hasil penilaian pada lembar validasi merupakan penilaian masing-masing validator terhadap perangkat pembelajaran, dianalisis berdasarkan rata-rata skor.

Bahan ajar MBNK dikatakan valid jika rata-rata skor masing-masing validator berada pada kategori baik atau sangat baik. Jika rata-rata skor menunjukkan bahan ajar pada kategori cukup, maka bahan ajar MBNK perlu adanya perbaikan. Hasil perbaikan digunakan untuk uji coba bahan ajar MBNK.

\section{HASIL PENELITIAN DAN PEMBAHASAN}

Berdasarkan komentar dan saran dari validator selanjutnya dievaluasi dan dilakukan revisi terhadap bahan ajar MBNK. Revisi bahan ajar MBNK yang dilakukan dapat dilihat pada tabel 1.

Tabel 1. Revisi Bahan Ajar MBNK

\begin{tabular}{lll}
\hline No & \multicolumn{1}{c}{ Komentar/Saran Validator } & \multicolumn{2}{c}{ Tindak Lanjut/Revisi } \\
\hline 1. & Ukuran huruf perlu diperbaiki & $\begin{array}{l}\text { Ukuran huruf telah diperbaiki } \\
\text { sehingga menjadi lebih jelas. }\end{array}$ \\
\hline 2. & Tampilan awal kurang menarik & $\begin{array}{l}\text { Tampilan awal sudah di edit } \\
\text { sedemikian rupa sehingga lebih } \\
\text { menarik. }\end{array}$ \\
\hline 3. & $\begin{array}{l}\text { Penulisan soal ada yang kurang sesuai, } \\
\text { jadi perlu diteliti lagi. }\end{array}$ & Soal-soal telah diperbaiki dan diteliti. \\
\hline 4. & $\begin{array}{l}\text { Perlu dimuat kunci jawaban dan } \\
\text { pembahasan soal }\end{array}$ & $\begin{array}{l}\text { Subbagian soal dalam playstore telah } \\
\text { memuat kunci jawaban dan } \\
\text { pembahasan soal }\end{array}$ \\
\hline
\end{tabular}

Berikut ini merupakan beberapa screenshot bahan ajar MBNK sebelum adanya revisi. 
Salafudin'1), Santika Lya Diah Pramesti²), Juwita Rini³)

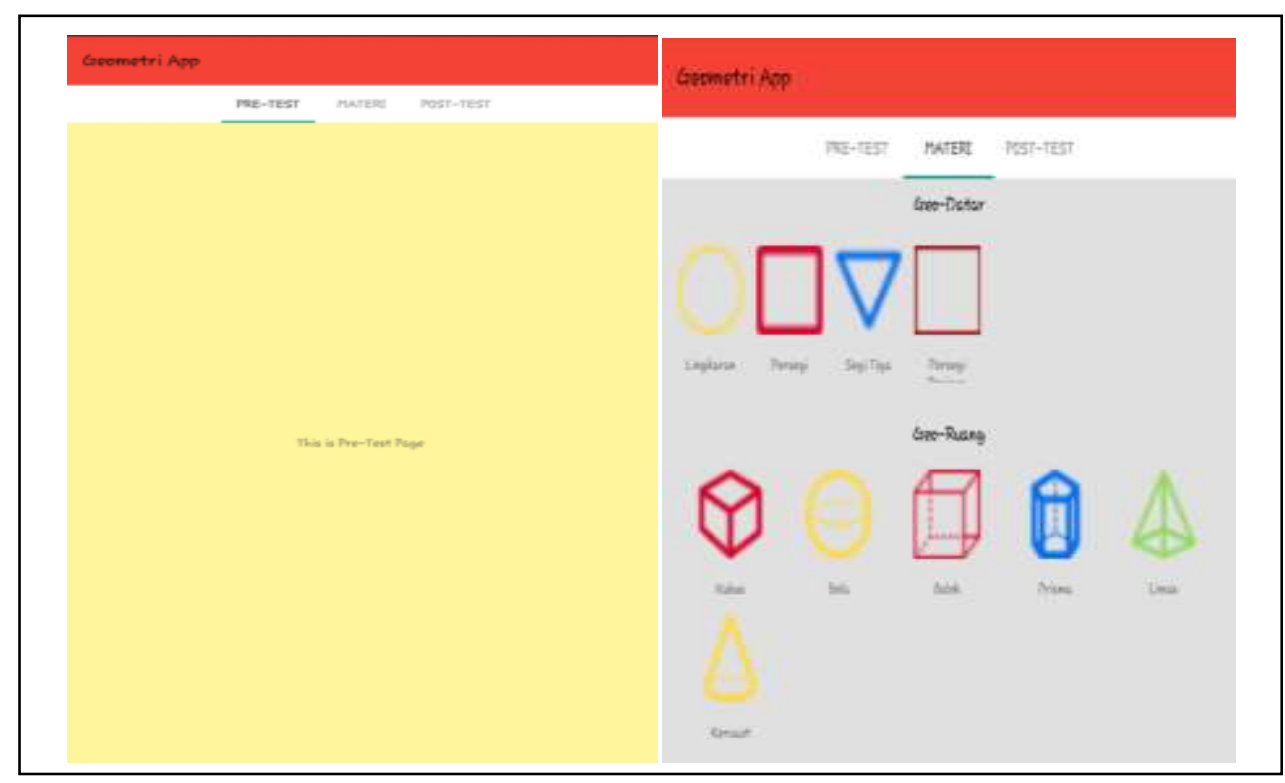

Gambar 2. Bahan Ajar MBNK Sebelum Revisi

Berikut ini merupakan beberapa screenshot bahan ajar MBNK setelah revisi. Bahan ajar geometri MBNK ini dapat diunduh pada aplikasi google playstore dengan nama "Geometri MBNK".

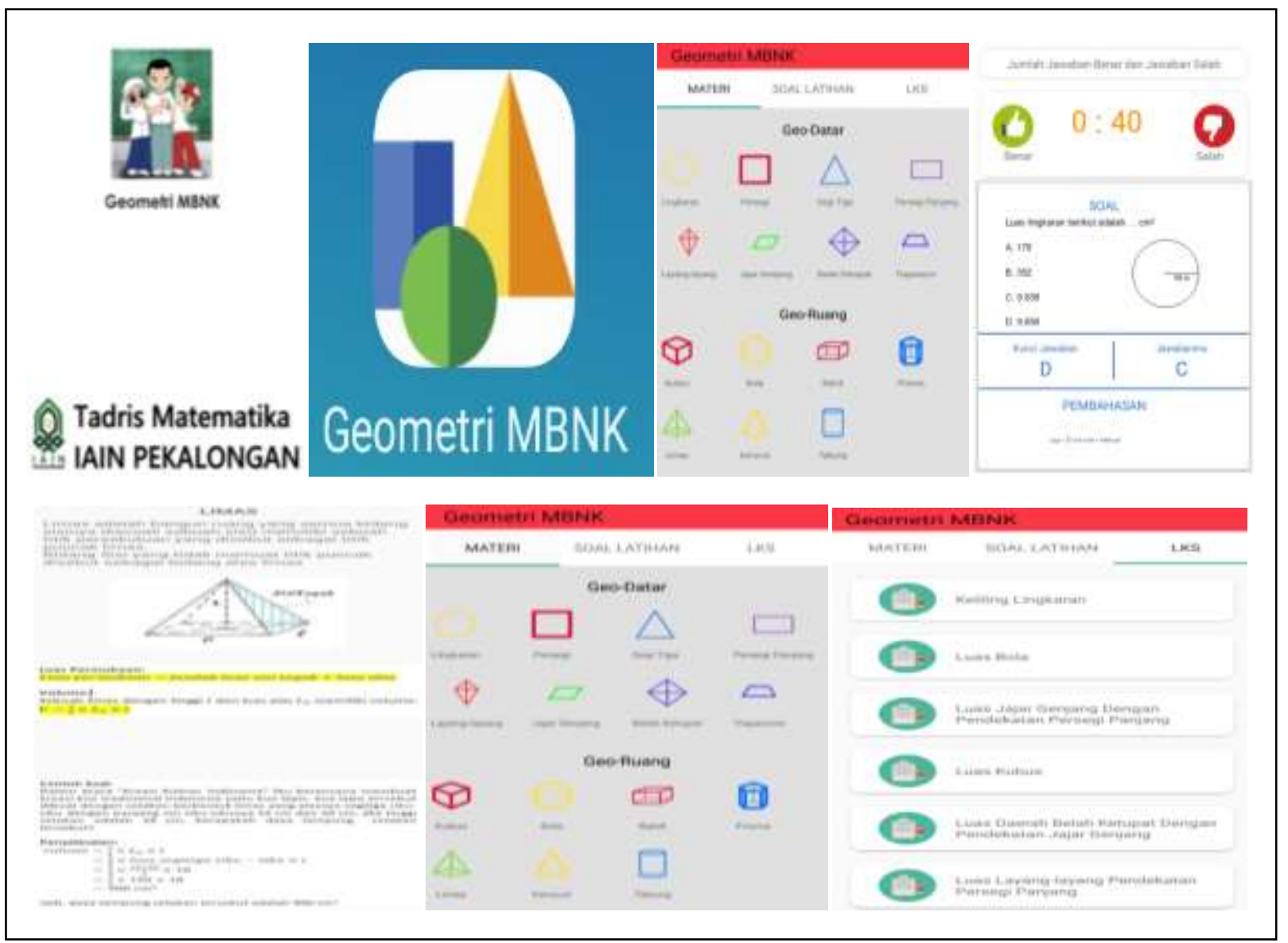

Gambar 3. Bahan Ajar MBNK Sesudah Revisi

26| Volume 6, No 1, June 2018 
Revisi mengenai soal-soal dalam bahan ajar diarahkan selalu memuat nilai nasionalisme dan atau kemandirian. Revisi tentang kegrafisan diarahkan untuk menghasilkan bahan ajar yang menarik perhatian dan minat orang yang sudah mendownload aplikasi dan menggunakannya. Keseluruhan revisi yang dilakukan bertujuan menampilkan dan menyusun bahan ajar matematika yang valid serta memuat nilai nasionalisme dan kemandirian sehingga diharapkan dapat meningkatkan kemampuan matematika siswa.

Butir soal pre-test dan post-test sebelum digunakan dianalisis menggunakan uji validitas, reliabilitas, taraf kesukaran dan daya pembeda. Soal yang telah dibuat tersebut selanjutnya diuji validitas isinya oleh ahli dan praktisi, setelah dinyatakan valid maka soal diujicobakan kepada responden. Berdasarkan komentar dan saran dari validator dilakukan evaluasi dan ditindaklanjuti dengan melakukan revisi pada bagian yang perlu diperbaiki. Butir soal tes hasil belajar yang dirancang sebanyak 20 butir soal, dari materi geometri. Setiap indikator dibuat 2-3 butir soal. Revisi TKMBNK dapat dilihat pada tabel 2.

Tabel 2. Revisi TKMBNK

\begin{tabular}{cll}
\hline No & Komentar/Saran Validator & \multicolumn{1}{c}{ Tindak Lanjut/Revisi } \\
\hline 1. & $\begin{array}{l}\text { Menggunakan masalah-masalah } \\
\text { yang lebih memunculkan nilai } \\
\text { nasionalisme dan kemandirian }\end{array}$ & $\begin{array}{l}\text { Menggunakan masalah-masalah yang } \\
\text { menggunakan nilai-nilai nasionalisme dan } \\
\text { kemandirian }\end{array}$ \\
\hline 2. & Gambar yang lebih di perjelas & Gambar yang sudah diperjelas \\
\hline 3. & $\begin{array}{l}\text { Penggunaan angka yang tidak } \\
\text { realistic }\end{array}$ & $\begin{array}{l}\text { Angka pada soal sudah di sesuaikan } \\
\text { dengan permasalahan }\end{array}$ \\
\hline
\end{tabular}

Analisis data kepraktisan bahan ajar MNBK yang digunakan adalah analisis data respons siswa dan guru terhadap bahan ajar MBNK. Adapun teknik analisis data yang digunakan untuk menguji keefektifan bahan ajar MBNK dalam penelitian ini menggunakan statistik uji $t$ sampel berpasangan, dengan terlebih dahulu dilakukan uji normalitas dan homogenitas terhadap data pre-test dan post-test sebagai uji prasyarat sebelum melakukan uji $\mathrm{t}$ berpasangan, sehingga diperoleh data berdistribusi normal dan diketahui bahwa kemampuan siswa dalam satu kelas tersebut sama (homogen).

Uji normalitas dan homogenitas, data hasil TKMBNK masing-masing kelas diperoleh hasil bahwa data berdistribusi normal dan homogen. Selanjutnya dilakukan uji beda rata-rata untuk mengetahui apakah rata-rata kedua kelas sama atau tidak. Hasil uji beda rata-rata masing-masing kelas diperoleh sebagai berikut. 
a. Uji Beda Rata-Rata Kelas Eksperimen A

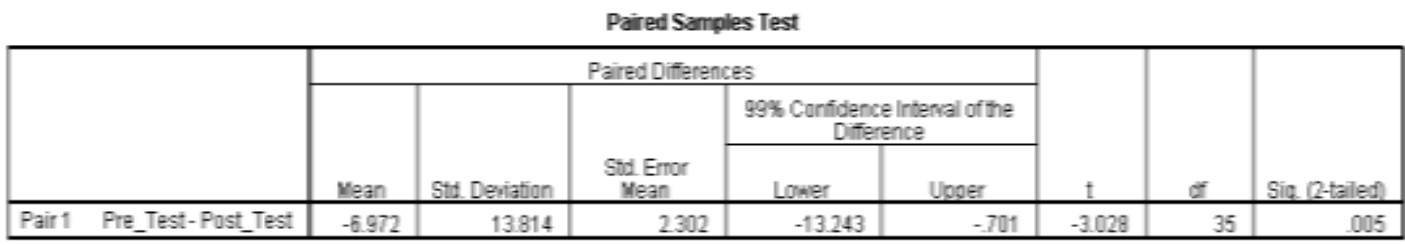

Berdasarkan output SPSS di atas, perhitungan menggunakan rumus uji banding pada SPSS, diperoleh nilai sig sebesar 0,005. Karena Sig $(0,005)<a$ $(0,01)$ maka dapat disimpulkan bahwa hasil belajar matematika siswa kelas A pada pokok bahasan geometri sesudah menggunakan bahan ajar matematika berwawasan nasionalisme dan kemandirian lebih baik daripada hasil belajar matematika siswa sebelum menggunakan bahan ajar matematika berwawasan nasionalisme dan kemandirian.

b. Uji Beda Rata-Rata Kelas Eksperimen B

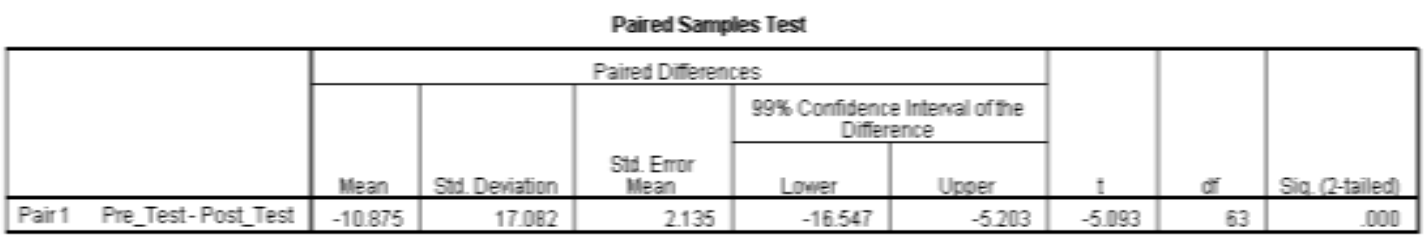

Perhitungan menggunakan rumus uji banding pada SPSS, diperoleh nilai sig sebesar 0,000. Karena Sig $(0,00)<$ a $(0,01)$ maka dapat disimpulkan bahwa hasil belajar matematika siswa kelas B pada pokok bahasan geometri sesudah menggunakan bahan ajar matematika berwawasan nasionalisme dan kemandirian lebih baik daripada hasil belajar matematika siswa sebelum menggunakan bahan ajar matematika berwawasan nasionalisme dan kemandirian.

c. Uji Beda Rata-Rata Kelas Eksperimen C

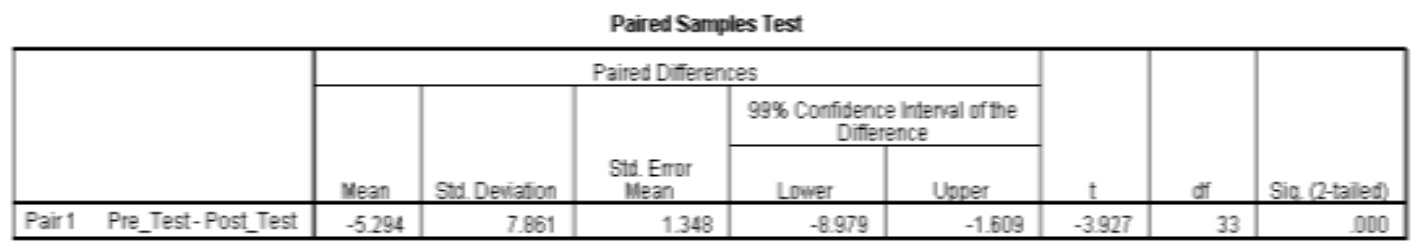

Berdasarkan perhitungan SPSS diperoleh nilai sig sebesar 0,000. Karena Sig $(0,00)<$ a $(0,01)$ maka dapat disimpulkan bahwa hasil belajar matematika siswa kelas C pada pokok bahasan geometri sesudah menggunakan bahan ajar matematika berwawasan nasionalisme dan kemandirian lebih baik daripada hasil belajar matematika siswa sebelum menggunakan bahan ajar matematika berwawasan nasionalisme dan kemandirian.

Keseluruhan pembahasan menunjukkan bahwa proses pengembangan bahan ajar dalam penelitian ini telah melalui tahap validasi, revisi, dan uji coba yang memadai sampai akhirnya diperoleh produk berupa draft akhir perangkat 28| Volume 6, No 1, June 2018 
pembelajaran. Hal ini berarti bahwa penelitian ini telah menghasilkan bahan ajar matematika MBNK yang valid. Tahap uji coba perangkat juga telah menghasilkan respon siswa positif, respon guru baik. Ini berarti bahan ajar matematika MBNK praktis. Uji coba bahan ajar matematika MBNK telah menunjukan hasil berupa: (1) kemampuan pemecahan masalah siswa kelas uji coba bahan ajar matematika MBNK lebih tinggi dari sebelumnya, (2) nilai karakter nasionalisme siswa berada pada kategori nasionalis, dan (3) nilai karakter kemandirian siswa berada pada kategori mandiri. Dari ketiga hal tersebut berarti uji coba bahan ajar matematika MBNK efektif digunakan.

Bahan ajar Geometri matematika berwawasan nasonalisme dan kemandirian ini setelah mendapat validasi, revisi, dan telah diujicobakan kemudian diupload di google playstore. Bahan ajar Geometri MBNK juga disajikan dalam google playstore dengan keywords "geometri", "matematika", "bahan ajar". Selain memuat materi, bahan ajar ini juga memuat contoh soal, latihan soal, dan LKS yang berwawasan nasionalisme. Setiap soal didesain dengan wawasan nasionalisme dan menuntut kemandirian siswa.

\section{SIMPULAN}

Secara umum, hasil validasi terhadap bahan ajar matematika berwawasan nasionalisme dan kemandirian (MBNK) mendapatkan kriteria sangat baik, respon siswa memberikan respons positif serta respons guru terhadap bahan ajar MBNK termasuk kategori baik. Hasil pengembangan bahan ajar geometri MBNK berpengaruh terhadap hasil belajar siswa. Hasil analisis dari pre-test dan post-test menunjukkan bahwa terdapat perbedaan rata-rata antara hasil pre test dan post test, yaitu lebih tinggi hasil belajar siswa yang menggunakan bahan ajar MBNK. Oleh karena itu, dapat ditarik kesimpulan bahwa terdapat perbedaan yang signifikan antara hasil belajar matematika siswa sebelum dan sesudah menggunakan bahan ajar MBNK.

\section{DAFTAR PUSTAKA}

Jujun, S. S. (2001). Pengajaran geometri di sekolah-sekolah Indonesia. IKIP Surabaya.

Malik, F. (2005). Holistika pemikiran pendidikan. Bandung: PT. Raja Grafindo Persada.

Mantiri, V. (2014). Perilaku menyimpang di kalagan remaja di Kelurahan Podang, Kecamatan Amurang Timur, III (1), 1-13. Retrieved from https://media.neliti.com/media/publications/90282-ID-perilakumenyimpang-di-kalangan-remaja-d.pdf

Mu'in, F. (2011). Pendidikan karakter konstruksi teoritik \& praktik. Yogyakarta: Ar-Ruzz 
Media.

Muhibuddin, H. (2014). Arah baru pendidikan Islam (Republika). Jakarta.

Mulyadi. (2011). Pengantar studi Islam. Jakarta: Ushul Press.

Musfiqi, S., \& Jailani, J. (2014). Pengembangan bahan ajar matematika yang berorientasi pada karakter dan Higher Order Thinking Skill (HOTS). PYTHAGORAS: Jurnal Pendidikan Matematika, 9 (1), 45-59. https:// doi.org/10.21831/pg.v9i1.9063

Nur, F. (2017). Pengembangan bahan ajar matematika berdasarkan model KolbKnisley berbantuan geogebra sebagai upaya meningkatkan Higher Order Thinking Skill dan apresiasi siswa. MaPan : Jurnal Matematika dan Pembelajaran, 5 (1), 96-109.

Prastowo, A. (2013). Pengembangan bahan ajar tematik. Yogyakarta: Diva Press.

Thiagarajan, S. S. (1974). Instructional development for training teachers of exceptional children. Indiana: Indian University Bloomington.

Usmaedi. (2017). Menggagas pembelajaran HOTS pada anak usia dini sekolah dasar. Jurnal Pendidikan Sekolah Dasar, 3 (1), 82-95.

Yunus, M. \& Suyitno, H. (2013). Pembelajaran TSTS berbasis kontruktivisme berbantuan CD pembelajaran untuk menumbuhkan kemampuan komunikasi matematis siswa. Unnes Journal of Mathematics Education Research, 2 (1). 